\title{
SUID-AFRIKA SE NASIONALE PARKE SISTEEM - WAT VAN DIE TOEKOMS?
}

\section{Sy Edele H SCHOEMAN*}

\section{Minister van Landbou \\ Republiek van Suid-Afrika}

Abstract - The significance of the 50th anniversary of the National Parks Board of Trustees is highlighted and homage is paid to all those who have contributed to the development of the national parks system in the Republic of South Africa. The Government never lightly refuses requests on sustained pressures for new national parks and establishment of a new National Park near Beaufort West in the Karoo, is announced.

Mnr die Voorsitter, uitgelese gaste, dames en here. U sal my toelaat om reg by die begin verskoning te maak dat Sy Edele Minister $\mathrm{H}$ Schoeman nie aanwesig kan wees nie weens omstandighede buite sy beheer. U sal my ook toelaat om sommer nou aan die voorsitter 'n woordjie toe te voeg van 'n belofte wat hy gemaak het en dit is toe hy ons uitgenooi het na hierdie funksie, dat ek hier kan kom en op my gemak kom sit en die tydjie in die Wildtuin net kan geniet. Hy het die belofte egter vergeet, ek is seker daarvan. Maar, weens omstandighede buite die beheer van Sy Edele die Minister, moet ek nou vandag hier optree soos wat dit in Engels gestel word "I am deputising, true to the real meaning of what a Deputy Minister means". U weet Minister Schoeman het van tyd tot tyd gesê 'n Adjunk-minister is $50 \%$ van niks en ek dink hy is nie baie ver uit nie!

Mnr die Voorsitter, u sal my dit vergun dat ek vir u gelukwens met $\mathrm{u}$ persoonlike verjaardag. Ons weet dat $\mathrm{dr}$ Knobel 'n besondere vindingryke persoonlikheid is. Ek wil hom nie blameer en ek glo nie iemand hier in die gehoor sal hom blameer, dat hy dit so bewerkstellig het dat die Nasionale Parkeraad se verjaardag saamval met sy eie nie. Maar ek wil dit darem net as 'n opmerking laat dat ek nie 'n enkele amptenaar ken, maak nie saak van watter status, wat so vindingryk is om te sorg dat soveel uitgelese gaste sy verjaardag bywoon nie! Ek wil hom gelukwens daarmee en daarmee gaan dit ook na mev Knobel. Ons weet dat sy hom beslis in alles bystaan en beslis veel kleur gee aan dit wat hy doen. Ons hoop dat hulle hierdie jaar wat voorlê, baie sal geniet en dat u ook veel

*Referaat voorgedra deur Sy Edele J J Malan, Adjunk-Minister van Landbou. 
sukses sal hê met $u$ werk hierso as Hoofdirekteur van die Nasionale Parkeraad.

Waar ek namens Minister Schoeman hier optree wil ek dan ook hoop dat $\mathrm{u}$ sover 'n besondere vrugbare simposium gehad het en as ek geluister het na wat dr. Martiny hier as opsomming aan ons voorgehou het, is ek jammer dat ek nie die hele tyd hier kon gewees het nie. Dit wil my voorkom onder andere, en dan is ek heeltemal objektief, dat iemand uit ons Departement Landbou-tegniese Dienste minstens gesorg het dat die boer se standpunt hier gestel is en dat $u$ u voete op die grond hou. Dit is vir my baie interessant toe dr. Martiny gepraat het, en waar hy dit so mooi gestel het dat daar selfs van owerheidsweë meer gedoen moet word, kon ek egter nie help as om daaraan te dink dat dit darem eienaardig is dat mense nie die essensie van dinge snap nie. Wanneer'n demokratiese land soos ons s'n aan mense eise stel, verwagtinge na vore bring, dan sê hulle by implikasie, ons wil dit hê, en ons is gewillig om daarvoor te betaal. Dit is ook waar ek 'n probleem het met die regering. U weet ek het drie besware teen die regering t.w.: as jy hulle nader dan het hulle probleme in die eerste instansie met finansies, in die tweede instansie het hulle probleme met verkryging van fondse en in die derde instansie het hulle probleme met geld!

Dit is vir my ' $n$ eer om vandag hier namens my Minister op te tree by hierdie besondere geleentheid. Dit is vir my dan ook aangenaam om sy toespraak hier aan u voor te lees.

Die bereiking van so 'n belangrike mylpaal as die 50ste verjaardag van die totstandkoming van die liggaam soos die Raad van Kuratore vir Nasionale Parke is ongetwyfeld 'n trotse gebeurtenis. Dit getuig van bestendigheid en dat die liggaam tot groot hoogte die taak wat aan hom opgedra is suksesvol uitgevoer het. Geen liggaam wat nie redelikerwys voldoen aan die eise wat aan hom gestel word, sal 50 jaar lank kan bestaan en gedy nie. Op 'n dag soos hierdie is dit paslik om 'n terugblik te werp in die verlede. By so ' $n$ terugblik is dit baie duidelik dat daar veral rede is tot groot dankbaarheid, maar ook om trots te kan wees.

Soos ook elders vandag by ' $n$ ander geleentheid staan ons in groot ootmoed en erkentlikheid voor die herinnering van die historiese figuur Paul Kruger. Aan hom kom die hulde toe vir sy grootmoedigheid en gebruiklike versiendheid om in die pionierstyd van die ontwikkeling van ons land en volk reeds 'n gebied af te sonder wat die natuur in sy ongeskonde staat bewaar en sou beskerm. Hy staan natuurlik nie alleen in die opsig nie, maar aan die voorpunt van 'n lang ry mense, wat groot bydraes gelewer het tot die totstandkoming en ontwikkeling van hierdie en ons ander nege nasionale parke. Daar was lede van die regering van ons land wat van tyd tot tyd groot entoesiaste van natuurbewaring was en wat deur regeringsoptrede die ontwikkeling van die stelsel van ons nasionale parke bevorder het. Ek verswyg liewer hulle name omdat dit seker is dat wanneer ek hulle probeer noem die name van sommige van hulle onregverdiglik weggelaat sal word. 
Mr Chairman, we cherish the memory of many private individuals who have already passed away but who during their lifetimes were enthusiastic nature lovers and contributed to the development of our national parks by the grant of land, money and other gifts. It is gratifying to know that also the present generation has not been lacking in displaying the true participation in our company here today and who have also made many material and substantial contributions both in money and in respect of services rendered towards the further development of our national parks. It is only because I realise that they would not like to advertise the fact that they are serving the country also in this respect, that I refrain from mentioning their names. We remember the many persons who have served as members of the National Parks Board of Trustees. Some of them with distinction. It is a fact that the Board has created an image of itself which is looked upon by many people with such high respect that they regard an appointment to the Board as the highest achievement possible.

Dit is interessant om net daaraan te dink - hulle sê dit word oorvertel in die wandelgange van die Parlement "... that the definition of a National Park is a place where people are sent when they are tired and need to relax, but appointment to the Board is for those who have spent their lives there!'”.

Ons neem vandag afskeid van een van die dienende lede van die Parkeraad. Hy is mnr Tiny Faure. Hy het met onderskeiding en met groot toewyding as lid van die Parkeraad gedien vir nie minder as 26 jaar nie. Oom Tiny sou seker nog graag voortgegaan het as lid van die Parkeraad as dit nie was dat hy noodwendig sy aktiwiteite wil begin inkort nie. Ek sê dankie aan hom vir sy lange jare van uitmuntende diens as lid van die Raad en wens hom die allerbeste toe op die pad vorentoe. Ons is jammer om te hoor dat mev. Faure nie so wel is nie en ons wil graag dit wat ons van Oom Tiny sê, dat hy dit aan haar sal oordra. Ons is dankbaar ook teenoor haar vir wat sy gedoen het en ons wens is dat sy geheel-en-al sal herstel.

Ons dink ook aan die aandeel van die amptenare van die Raad oor die jare. Die van hulle wat vandag nog in die diens van die Parkeraad is, diegene wat die Parke geskep het, waarop ons so trots is en wat aan ons volk en aan ons mense asook mense van oor die hele wêreld so 'n unieke vreugde en genot verskaf. Ons wil ook met groot waardering verwys na die verskillende Staatsdepartemente en ander owerheidsinstansies wat oor die jare steeds uiters simpatiek opgetree het wanneer hulle met sake van die Nasionale Parkeraad te doen gekry het. Hierdie welwillendheid het in 'n aansienlike mate die totstandkoming en ontwikkeling van ons Nasionale Parke moontlik gemaak.

Mr Chairman, we regard what has been achieved in the field of nature conservation in our country with justifiable pride. Nature conservation in what may be termed national parks, is rightly the function of the National Parks Board of Trustees. National Parks to my mind are 
necessary to protect and nourish the continued existence of objects of nature for the benefit of the nation, where such conservation bears a national character and calls for action on a national scale. Enthusiasts from the ranks of the Board and its officials and other nature lovers are continually pressing for the creation of further national parks, or for the extension of their areas, or for improvements of the facilities in existing national parks. I wish to assure them that the Government never lightly refuses these requests in this regard and I am sure the Chairman will bear me out on that.

Hoe graag ookal die regering hoogsprioriteit sal wil verleen aan aansoeke om ondersteuning van die Nasionale Parkeraad is hy nogtans soms verplig om sulke aansoeke af te wys. Dit gebeur in elk geval nie dikwels nie. Daarmee moet egter rekening gehou word dat aansprake op die land se bates, veral in die vorm van grond en geld geweldig is, en dat dit al hoe moeiliker word om selfs die verdienstelikste voorstelle te bevredig. Dit is vir my as Minister van Landbou ook 'n voorreg om te kan getuig dat in die Landbou, van die grootste gedeelte van die oppervlakte van ons land wat landboukundig aangewend word, die belangrikheid van bewaring van die gawes van die natuur in die vorm van landbouhulpbronne oor die jare heen al hoe meer besef word.

Vandag is juis hierdie aspek een van die belangrikste onderdele van die boerdery. Ek mak die stelling dat geweldig baie reeds gedoen word om die gawes wat die natuur ons vaderland bied, te beskerm en te bewaar. Ook is daar groot vordering gemaak met die inskerping van 'n nasionale bewustheid van die waarde van ons natuurlike hulpbronne by die publiek. Terwyl ons erken dat baie meer nog gedoen moet word, hoef ons land nie skaam te wees vir wat reeds bereik is en wat tans onderneem word nie.

Moontlik moet ondersoek ingestel word of daar met inagneming van beskikbare fondse nie uitbreidings aan die volgende aksies bewerkstellig kan word nie. Ek noem hulle:

(a) Ek dink dat dit noodsaaklik is om te kyk tot watter mate die Bergkwagga Nasionale Park, die Bontebok Nasionale Park en die Tsitsikamabos en -seekus Nasionale Park vergroot kan word. Dat dit nodig is, is seker. Of dit gedoen kan word, dit moet die toekoms bepaal.

(b) Die stigting van nuwe nasionale parke om meeste van die volgende belangrike gebiede te bewaar: die Rigtersveld; sommige voëleilande en robeilande aan ons kuste; die Kosibaai-kompleks; deel van die Sederberge; deel van die Drakensberg eskarpement; 'n Namakwaland blommepark; die Bobbejaanskloof; 'n Grot Nasionale Park en dan natuurlik 'n Karoo Nasionale Park.

Dit is dan met groot vreugde dat ek kan aankondig dat die Kabinet in beginsel goedkeuring verleen het aan die stigting van 'n Karoo Nasio- 
nale Park by Beaufort-Wes. Die Park word moontlik gemaak deur 'n wonderlike skenking van grond op die dorpsmeent deur die Munisipaliteit van Beaufort-Wes. Die Munisipaliteit word vandag hier verteenwoordig en ons sê baie dankie vir die besondere bydrae deur 'n enkele munisipaliteit vir 'n skenking wat 'n groot nasionale bate gaan word. Tot hierdie grond word bygevoeg grond wat bygekoop word deur gelde voorsien deur die Suid-Afrikaanse Natuurstigting wat bykans R100 000 beloop asook ' $n$ bedrag uit die Staatskis van R100 000. Die SuidAfrikaanse Natuurstigting wat hier verteenwoordig word, moet spesiale vermelding kry omdat hulle dit reggekry het om gelde van die algemene publiek en veral skoolkinders vir die doel in te samel. Ek dink dit was 'n besonderse poging.

Ons wil die Stigting en deur hulle aan almal wat bygedra het tot die Karoo Parkefonds baie dankie sê. Ons vertrou dat die wonderlike aksie wat hulle begin het, voortgesit sal word en dit die algemene publiek meer en meer sal aanspoor om grond vir nasionale parke te verkry, sodat die Raad nie net na die staat hoef te kyk vir die verkryging van fondse nie. Die gronde bly 'n volksbesit en dit gee my dus groot vreugde om op die 50 ste bestaansjaar van die Nasionale Parkeraad die stigting van die 10de nasionale park te mag aankondig.

Ek sluit af met die gedagte, mnr die Voorsitter, dat die Nasionale Parkeraad veral kan trots wees op wat hy tot stand gebring het. Die hele land kan trots wees op wat tot stand gebring is en kan spog met dit wat die Raad opgebou het. Ons is dankbaar daarvoor en ons vertrou dat die Raad op die pad vorentoe net soveel sukses sal hê as op die pad wat reeds agter lê. Mag die ideale wat vir die toekoms gekoester word, almal bewaarheid word. Baie dankie. 